\title{
Isolation and kinetic properties of arginase in the gut of grasshopper (Zonocerus variegatus Linn)
}

\author{
R. E. OKONJI ${ }^{1 *}$, O. L. EHIGIE ${ }^{2}$ and F. K. AGBOOLA ${ }^{1}$ \\ ${ }^{1}$ Department of Biochemistry, Obafemi Awolowo University, Ile-Ife, Nigeria. \\ ${ }^{2}$ Department of Biochemistry, Ladoke Akintola University of Technology, Ogbomoso, Nigeria. \\ *Corresponding author; email: okonjire@yahoo.co.uk;reokonji@oauife.edu.ng
}

\begin{abstract}
Arginase (EC 3.5.3.1) catalyzes the hydrolysis of arginine to ornithine and urea. Arginase was purified and characterized from the gut of Zonocerus variegatus through DEAE-cellulose and biogel-P100 gel filtration chromatography. The specific activity of the enzyme was $3.7 \mu$ moles/min per $\mathrm{mg}$ of protein and a yield of $14.7 \%$. An apparent molecular weight of 143,000 daltons was estimated by gel filtration on biogel P-100. The Michaelis constant $\left(\mathrm{K}_{\mathrm{m}}\right)$ of the enzyme was $40 \mathrm{mM}$ with arginine as substrate. The optimum $\mathrm{pH}$ was 8.0 and the optimum temperature was $40{ }^{\circ} \mathrm{C}$ for $Z$. variegatus arginase. The enzyme was stable up to $40{ }^{\circ} \mathrm{C}$ for $20 \mathrm{~min}$ and lost all of its activity at $80^{\circ} \mathrm{C}$. The enzyme was specific for arginine as substrate. The enzyme was strongly enhanced in the presence of $\mathrm{Mn}^{2+}, \mathrm{Na}^{+}, \mathrm{NH}_{4}^{+}$and $\mathrm{Hg}^{2+}$ showed similar activation. $\mathrm{Ni}^{2+}$ and $\mathrm{Zn}^{2+}$ slightly inhibited Z. variegatus. Chelating (EDTA, citrate, ascorbic acid and urea) and thio (2-mercaptoethanol and cystein) compounds inhibited the activity of arginase in Z. variegatus. While amino acids (proline, lysine, aspartate and valine) showed no inhibition on arginase activity. The presence of arginase in the gut of Zonocerus variegatus could be for other functions rather than urea production in urea cycle.

(C) 2013 International Formulae Group. All rights reserved.
\end{abstract}

Keywords: Arginase; Zonocerus variegatus; Distribution; Physicochemical Properties.

\section{INTRODUCTION}

The African variegated grasshopper Zonocerus variegatus (L.) (Orthoptera: Pyrgomorphidae), whose pest status was established about 50 years ago (COPR, 1974), feeds on numerous plant species, including the food crops banana, cassava, cocoa, citrus, cowpea and yam (Toye, 1982). However, not all the plant species it consumes contribute to the grasshopper's growth and development (Idowu and Sonde, 2004). For instance, cassava and Chromolaena odorata leaves support its growth and development, while Talinum triangulare and Aspilla africana leaves do not (Toye, 1982). Zonocerus variegatus is a polyphagous species capable of consuming most of the plant species in its surroundings (Toye, 1982), and is reported to consume more than 250 plant species among 71 families (Chiffaud and Mestre, 1990), among which are many crops, including citrus, cocoa, banana, and vegetables, such as cassava.

Arginase (L-arginine aminohydrolase; EC 3.5.3.1) catalyses degradation of Larginine to L-ornithine and urea, by elimination of guanidine group from arginine molecule (Hwang et al., 2001; Todd et al., 
2001; Sampaleanu et al., 2002; Ash, 2004). It is widely distributed in the biosphere and represented in all primary kingdoms (Jenkinson et al., 1996; Dabir et al., 2005). Arginase is widely distributed in insects, which are generally uricotelic. Despite this, the nutritional requirement of arginine by several species indicates that insects have a limited capacity to synthesize arginine (Pant and Kumar, 1978). Arginase plays a critical role in the hepatic metabolism of many higher organisms as a cardinal component of the urea cycle (Jenkinson et al., 1996). Additionally, it occurs in numerous organisms and tissues where there is no functioning urea cycle (Jenkinson et al., 1996; Yu et al., 2003; Ash, 2004; Mohamed et al., 2005). The detection of arginase practically in all insects, and of arginine, citrulline and ornithine in many, has been made at all stages of development (Pant and Kumar, 1978). However, the nutritional and enzymic studies hitherto made on them have not given any conclusive and unequivocal evidence regarding the operation of a Krebs-Henseleit urea cycle, and it still remains a disputed topic (Pant and Kumar, 1978). Prokaryotes and lower eukaryotes that contain arginase use it for some purpose other than as urea cycle component (Jenkinson et al., 1996). In mammalian liver, arginase functions principally in urea biosynthesis involving cyclic interconversion of ornithine and arginine (Jenkinson et al., 1996; Ash, 2004). The arginase activity present in the fat body tissue of three species of insects (the silkmoths Hyalophora gloveri and Antheraea polyphemus and the cockroach Blaberus cranifera) has been characterized. The aim of this study was to investigate the physicochemical properties of arginase present in the gut of Zonocerus variegatus with the goal of further understanding arginase physiological function in this insect.

\section{MATERIALS AND METHODS Materials Trizma base, Trizma-HCl, ethylenediamine tetraacetic acid (EDTA),}

DEAE Cellulose, p-dimethyl aminobenzaldelyde (Ehrlich reagent), were purchased from Sigma Chemical Company, St. Louis, Mo., USA. Sucrose, sodium chloride, ammonium sulphate (enzyme grade), glacial acetic acid, glycerol, and hydrochloric acid, were purchased from BDH Chemical Limited, Poole England. Acrylamide and N, $\mathrm{N}^{1}$-methylene bisacrylamide (MBA), ammonium persulphate, $\mathrm{N}, \mathrm{N}, \mathrm{N}^{1}, \mathrm{~N}^{1}$ tetramethylenediamine (TEMED) are from Eastman, Rochester, NY, USA. All other reagents were of analytical grade and were obtained from either Sigma or BDH. Zonocerus variegatus were collected from an abandoned farmland at the Ladoke Akintola University of Technology, Ogbomoso, Osun State, Nigeria, between October and November 2010.

\section{Methods \\ Arginase assay and protein determination}

Arginase activity was determined according to the method of Kaysen and Strecker (1973). The reaction mixture contained, in final concentration, $1.0 \mathrm{mM}$ Tris-HCl buffer, pH 9.5 containing $1.0 \mathrm{mM}$ $\mathrm{MnCl}_{2}, 0.1 \mathrm{M}$ arginine and $50 \mu \mathrm{l}$ of the enzyme preparation was added in a final volume of $1.0 \mathrm{ml}$. The mixture was incubated for 10 minutes at $37{ }^{\circ} \mathrm{C}$. The reaction was terminated by the addition of $2.5 \mathrm{ml}$ Erhlich reagent (that contains $2.0 \mathrm{~g}$ of p-dimethyl aminobenzaldelyde in $20 \mathrm{ml}$ of concentrated hydrochloric acid and made up to $100 \mathrm{ml}$ by adding distilled water).

The optical density reading was taken after 20 minutes at $450 \mathrm{~nm}$. The urea produced was estimated from the urea curve prepared by varying the concentration of urea between $0.1 \mu \mathrm{mol}$ and $1.0 \mu \mathrm{mol}$. The unit of activity of arginase is defined as the amount of enzyme that will produce one $\mu \mathrm{mol}$ of urea per min at $37{ }^{\circ} \mathrm{C}$. The protein concentration was routinely determined by the method of Bradford (1976) using bovine serum albumin (BSA) as standard. 


\section{Tissue extraction and purification}

All operations were carried out at temperatures between 0 and $37{ }^{\circ} \mathrm{C}$. Centrifugations were done at $10{ }^{\circ} \mathrm{C}$ using IECDPR Cold Centrifuge. All buffers contained $1.0 \mathrm{mM} \mathrm{MnCl}{ }_{2}$ (Kaysen and Strecker, 1973). $\mathrm{pH}$ measurement was made at $25{ }^{\circ} \mathrm{C}$ using Mettler MP200 Digital pH Meter.

The frozen grasshopper was allowed to thaw at room temperature and weighed. A total of $125 \mathrm{~g}$ (wet weight) of tissue was used for this preparation. The weighed mass of grasshopper was minced and homogenized in a Warring Blender for $1 \mathrm{~min}$ in nine volumes (v/w) of the homogenization buffer containing $0.25 \mathrm{M}$ sucrose and $0.01 \mathrm{M} \mathrm{MnCl}_{2}$ in $0.01 \mathrm{M}$ Tris- $\mathrm{HCl}$ buffer, $\mathrm{pH}$ 7.5. The homogenate obtained was stirred, occasionally, for one hour at $4{ }^{\circ} \mathrm{C}$ and then subjected to centrifugation at $6,000 \mathrm{rpm}$ at $10{ }^{\circ} \mathrm{C}$ for 30 min. The supernatant was filtered through a double layer of cheesecloth. The cellular debris was resuspended in one volumes of the homogenization buffer, homogenized in the Warring Blender and centrifuged under the same condition. The supernatant obtained was combined with that from the first centrifugation.

\section{DEAE-cellulose ion exchange} chromatography

A column $(2.5 \times 40 \mathrm{~cm})$ of treated DEAE-Cellulose was packed and equilibrated with $5 \mathrm{mM}$ Tris-HCl buffer, $\mathrm{pH}$ 7.2. The extract from the preceding step was then layered on the column. The column was first washed with $5 \mathrm{mM}$ Tris- $\mathrm{HCl}$ buffer, $\mathrm{pH} 7.2$ to remove unbound proteins, followed by elution with a $400 \mathrm{ml}$ linear gradient of $0-1 \mathrm{M} \mathrm{NaCl}$ in $5 \mathrm{mM}$ Tris- $\mathrm{HCl}$ buffer, $\mathrm{pH}$ 7.2. Fractions of $5 \mathrm{ml}$ were collected from the column that was maintained at a flow rate of $30 \mathrm{ml}$ per hour. Protein was monitored spectrophotometrically at $280 \mathrm{~nm}$. The fractions were also assayed for arginase activity. The active fractions were pooled and stored in the freezer.

\section{Gel filtration on biogel P-100}

Biogel P-100 gel filtration resin was washed with several changes of $5 \mathrm{mM}$ Tris-
$\mathrm{HCl}$ buffer, $\mathrm{pH}$ 7.5. This was then packed unto the column $(2.5 \times 90)$ and equilibrated with $5 \mathrm{mM}$ Tris-HCl buffer, $\mathrm{pH}$ 7.5. The enzyme fraction from the preceding step was then applied to the biogel P-100. Fractions of $4 \mathrm{ml}$ were collected at a flow rate of $10 \mathrm{ml}$ per hour. Protein was monitored spectrophotometrically at $280 \mathrm{~nm}$. The fractions were also assayed for arginase activity. The active fractions were pooled and stored in the freezer.

\section{Molecular weight determination}

The native molecular weight was determined on a biogel P-100 column $(2.5 \mathrm{x}$ $90 \mathrm{~cm})$. The standard proteins were $\alpha$ chymotrypsinogen A ( $\left.\mathrm{M}_{\mathrm{r}} 24,000 ; 10 \mathrm{mg}\right)$, ovalbumin $\left(\mathrm{M}_{\mathrm{r}} 45,000 ; 10 \mathrm{mg} / \mathrm{ml}\right)$, bovine serum albumin $\left(M_{\mathrm{r}}\right.$ 67,000; $\left.10 \mathrm{mg} / \mathrm{ml}\right)$, creatinine phosphokinase $\left(\mathrm{M}_{\mathrm{r}} 88,000 ; 10\right.$ $\mathrm{mg} / \mathrm{ml})$ and bovine arginase $\left(M_{r} 120,000: 10\right.$ $\mathrm{mg} / \mathrm{ml})$.

\section{Determination of kinetic parameters}

The kinetic parameters $\left(\mathrm{V}_{\max }\right.$ and $\left.\mathrm{K}_{\mathrm{m}}\right)$ of the enzyme were determined according to Kaysen and Strecker (1973). The $K_{m}$ of arginine was determined by varying the concentration of arginine between $40 \mathrm{mM}$ and $150 \mathrm{mM}$ in $2 \mathrm{mM}$ Tris- $\mathrm{HCl}$ buffer, $\mathrm{pH} 9.5$, in the presence of $0.01 \mathrm{mM} \mathrm{MnCl}_{2}$. The kinetic parameters were determined from the double reciprocal plot. Lines through the points were drawn by the method of regression.

\section{Substrate specificity studies}

The substrate specificity of grasshopper arginase was investigated by testing its activity towards structurally similar compounds with guanidino group. The compounds include L-arginine, Largininemonohyrochloride and guanidine chloride. The solutions of above compounds (30 $\mathrm{mM}$ ) were prepared in $2 \mathrm{mM}$ Tris- $\mathrm{HCl}$ buffer, $\mathrm{pH}$ 7.2. Enzyme activity was measured by spectrophotometric detection of urea as described by Kaysen and Strecker (1973). The reaction mixture contained, in final concentration, $1.0 \mathrm{mM}$ Tris- $\mathrm{HCl}$ buffer, $\mathrm{pH}$ 9.5 containing $1.0 \mathrm{mM} \mathrm{MnCl}_{2}, 30 \mathrm{mM}$ solution of the substrates and $50 \mu \mathrm{l}$ of the 
enzyme preparation was added in a final volume of $1.0 \mathrm{ml}$.

\section{Effect of temperature}

The activity of arginase was assayed at temperatures between $30{ }^{\circ} \mathrm{C}$ and $100{ }^{\circ} \mathrm{C}$ to investigate the effect of temperature on the activity of the enzyme. The assay mixture was first incubated at the indicated temperature for $10 \mathrm{~min}$ before the reaction was initiated by the addition of $50 \mu \mathrm{l}$ of the enzyme that had been equilibrated at the same temperature.

For the effect of heat on the stability of arginase, a $1 \mathrm{ml}$ aliquot of the enzyme solution was incubated at $30^{\circ} \mathrm{C}, 40^{\circ} \mathrm{C}, 50^{\circ} \mathrm{C}$, $60{ }^{\circ} \mathrm{C}, 70{ }^{\circ} \mathrm{C}, 80^{\circ} \mathrm{C}$ and $90{ }^{\circ} \mathrm{C} .50 \mu \mathrm{l}$ aliquot was withdrawn and assayed for residual activity at the indicated time. A plot of percentage residual activity against incubation time was made to determine the stability of the enzyme.

\section{Effect of pH on the enzyme activity}

The effect of $\mathrm{pH}$ on arginase was studied by assaying the enzyme using the following buffers of different $\mathrm{pH}$ values: 5 $\mathrm{mM}$ citrate buffer ( $\mathrm{pH}$ 5.0-6.5), $5 \mathrm{mM}$ phosphate $(\mathrm{pH}$ 6.5-8.0), $5 \mathrm{mM}$ Tris- $\mathrm{HCl}$ buffer ( $\mathrm{pH} 8.0-10.0)$. One milliliter $(\mathrm{ml})$ of the reaction mixture contained $2.5 \mathrm{mM}$ of the appropriate buffer, $0.1 \mathrm{M}$ arginine and $0.02 \mathrm{ml}$ enzyme preparation.

Effects of inhibitors on the activity of arginase from $Z$. variegatus

The inhibitory effects of amino acids on the activity of arginase were investigated on the enzyme with arginine as substrate. The effects of five amino acids on the activity of $Z$. variegatus arginase were studied. The amino acids used for the study includes Llysine, L-valine, L-proline, L-aspartic acid, and L-arginine. The amino acids $(25 \mathrm{mM})$ were used as inhibitors with the routine assay procedure.

The inhibitory effects of chelating compounds (EDTA, citrate and ascorbic acid) were studied. Enzyme preparation was incubated with $50 \mathrm{mM}$ of the required chelating compound at $\mathrm{pH} 7.5$ at $37^{\circ} \mathrm{C}$ for 30 min and aliquot tested for arginase activity.
Also the effects of 2-mercaptoehthanol and cystein were investigated by incubating $5 \mu \mathrm{M}$ each of the thiol compounds with $0.1 \mathrm{ml}$ of the enzyme solution for $1 \mathrm{hr}$. Aliquot was taken out for arginase assay.

\section{RESULTS}

\section{Enzyme purification}

The summary of purification is shown in Table 1. The elution profiles of the chromatographic step of the procedure are shown in Figures 1 and 2. The calibration curve on biogel P-100 for native molecular weight determination is shown in Figure 3. Gel filtration on biogel P-100 resulted in a molecular weight estimate of approximately 143,000 daltons.

\section{Kinetic parameters}

The Lineweaver-Burk plot for the reciprocal of initial reaction velocity versus reciprocal of the concentration of arginine is shown in Figure 3. Figures 4 and 5 shows the Lineweaver-Burk plot for the reciprocal of initial reaction velocity versus reciprocal of the concentration of guanidine chloride and arginine monohydrochloride respectively. A summary of the true Michealis constants, $K_{m}$ obtained, as well as the maximum velocity, $\mathrm{V}_{\max }$ values are presented in Table 2 .

\section{Effect of pH on the activity of Zonocerus variegatus arginase}

The activity of grasshopper arginase was determined in the buffer $\mathrm{pH}$ range from 6 to 11 at $37{ }^{\circ} \mathrm{C}$. The optimum $\mathrm{pH}$ of grasshopper arginase was at $\mathrm{pH} 8.0$ (Figure 6) in the presence of $\mathrm{MnCl}_{2}$.

Effect of temperature on the activity of Zonocerus variegatus arginase

The activity of grasshopper arginase was assayed at temperatures between $30^{\circ} \mathrm{C}$ and $100^{\circ} \mathrm{C}$. The optimum temperature of the enzyme was found to be $40{ }^{\circ} \mathrm{C}$ at $\mathrm{pH} 9.5$ (Figure 7). The effect of heat on the stability of arginase expressed as percentage is presented in Figure 8. The enzyme was 
inactivated at temperature above $40{ }^{\circ} \mathrm{C}$. The inactivation being more pronounced with increasing incubation temperature. At $80{ }^{\circ} \mathrm{C}$, the enzyme lost about $85 \%$ of its original activity within 10 minutes of incubation (Figure 8).

Effect of metal ions on the activity of Zonocerus variegatus arginase

The effect of metal ions is presented in Table 3. The activity of arginase in $Z$. variegatus was strongly enhanced in the presence of $\mathrm{Mn}^{2+}$. $\mathrm{Na}^{+}, \mathrm{NH}_{4}^{+}$and $\mathrm{Hg}^{2+}$ also showed similar activation of the enzyme. $\mathrm{Ni}^{2+}$ and $\mathrm{Zn}^{2+}$ slightly inhibited $Z$. variegatus arginase
Effect of chelating and thio compounds on the activity of Zonocerus variegatus arginase

Table 4 shows the effects of chelating (EDTA, citrate, ascorbic acid and urea) and thio (2-mercaptoethanol and cystein) compounds on the activity of arginase in $Z$. variegatus. The compounds showed complete inhibition of the enzyme.

Effect of amino acids on the activity of Zonocerus variegatus arginase

The effect of the amino acids is presented in Table 5. The activity of arginase was not affected by the two different concentrations of the amino acids.

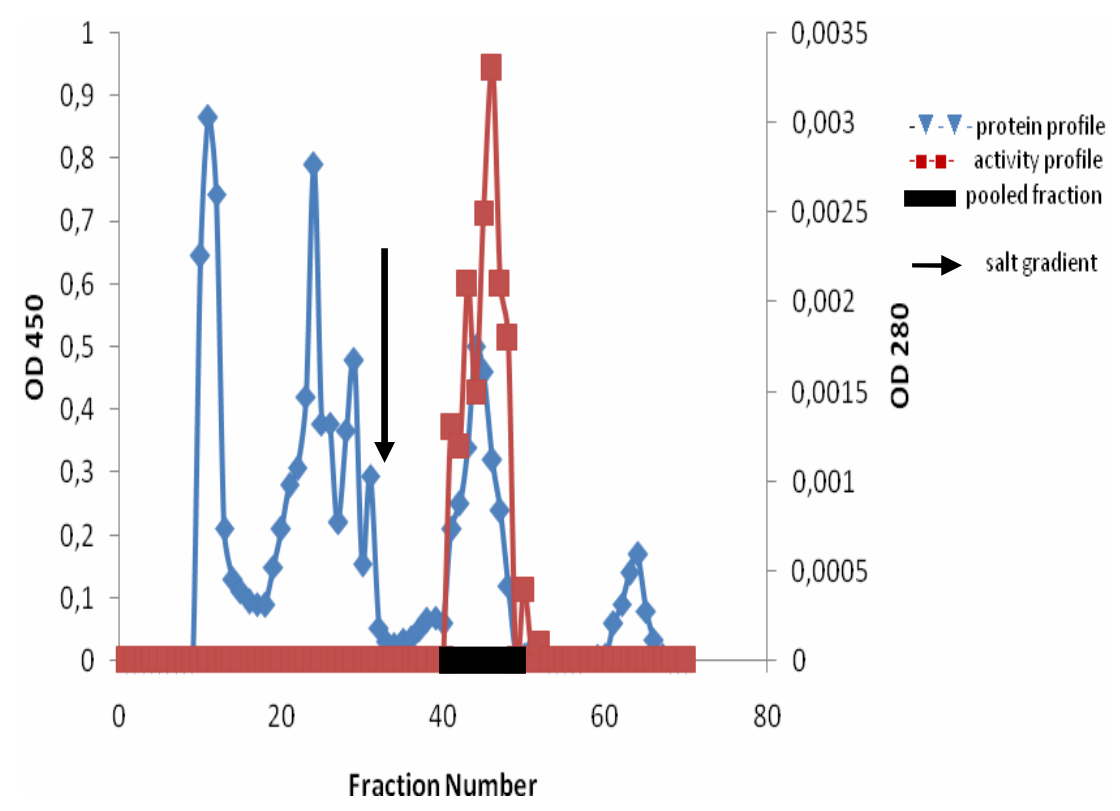

Figure 1: DEAE-cellulose ion exchange chromatography of Z. variegatus arginase. The column was first washed with $100 \mathrm{ml} 0.1 \mathrm{M}$ Tris- $\mathrm{HCl}$ buffer, $\mathrm{pH}$ 7.2. The enzyme solution was layered on the packed column and eluted with a $200 \mathrm{ml}$ linear gradient of $0-1 \mathrm{M} \mathrm{NaCl}$ in $0.1 \mathrm{M}$ Tris- $\mathrm{HCl}$ buffer, $\mathrm{pH}$ 7.2. Fractions of $5 \mathrm{ml}$ were collected from the column. 


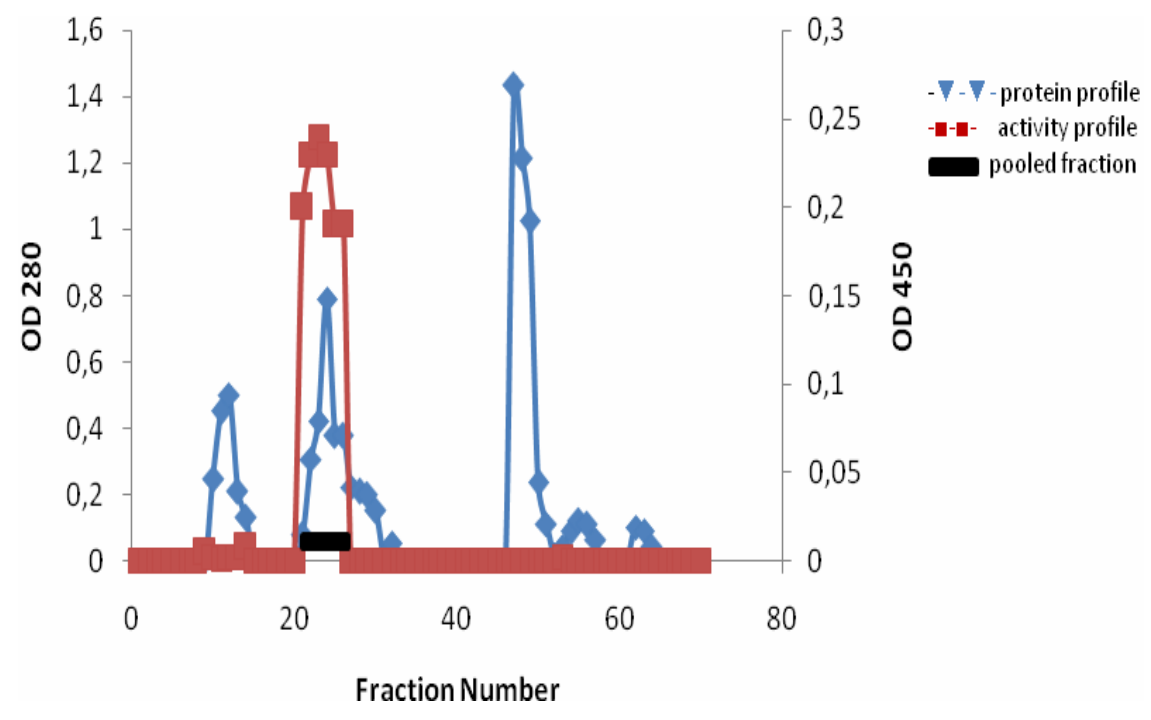

Figure 2: Gel flitration chromatography on biogel P-200 of Z. variegatus arginase. The column $(2.5 \times$ 90) was first equilibrated with $5 \mathrm{mM}$ Tris- $\mathrm{HCl}$ buffer, $\mathrm{pH}$ 7.5. The enzyme fraction from the preceding step was then applied to the column. Fractions of $4 \mathrm{ml}$ were collected at a flow rate of $10 \mathrm{ml}$ per hour.

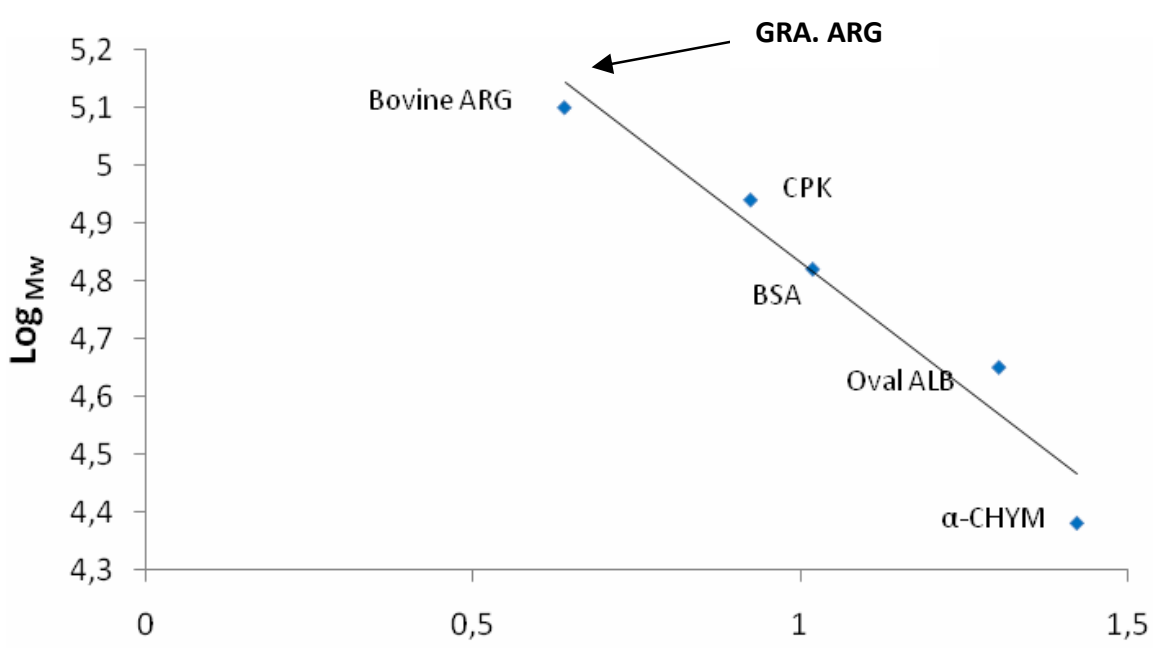

Figure 3: Calibration curve on biogel P-100 for native molecular weight determination of $Z$. variegatus arginase. The native molecular weight was determined on a Biogel P-100 column $(2.5 \times 90 \mathrm{~cm})$. The standard proteins as indicated on the curve are $\alpha$-CHYM ( $\alpha$-chymotrypsinogen A), Oval ALB (ovalbumin), BSA (bovine serum albumin), CPK (creatinine phosphokinase) and Bovine ARG (bovine arginase). Grasshopper arginase (GRA. ARG) is indicated by the arrow. 


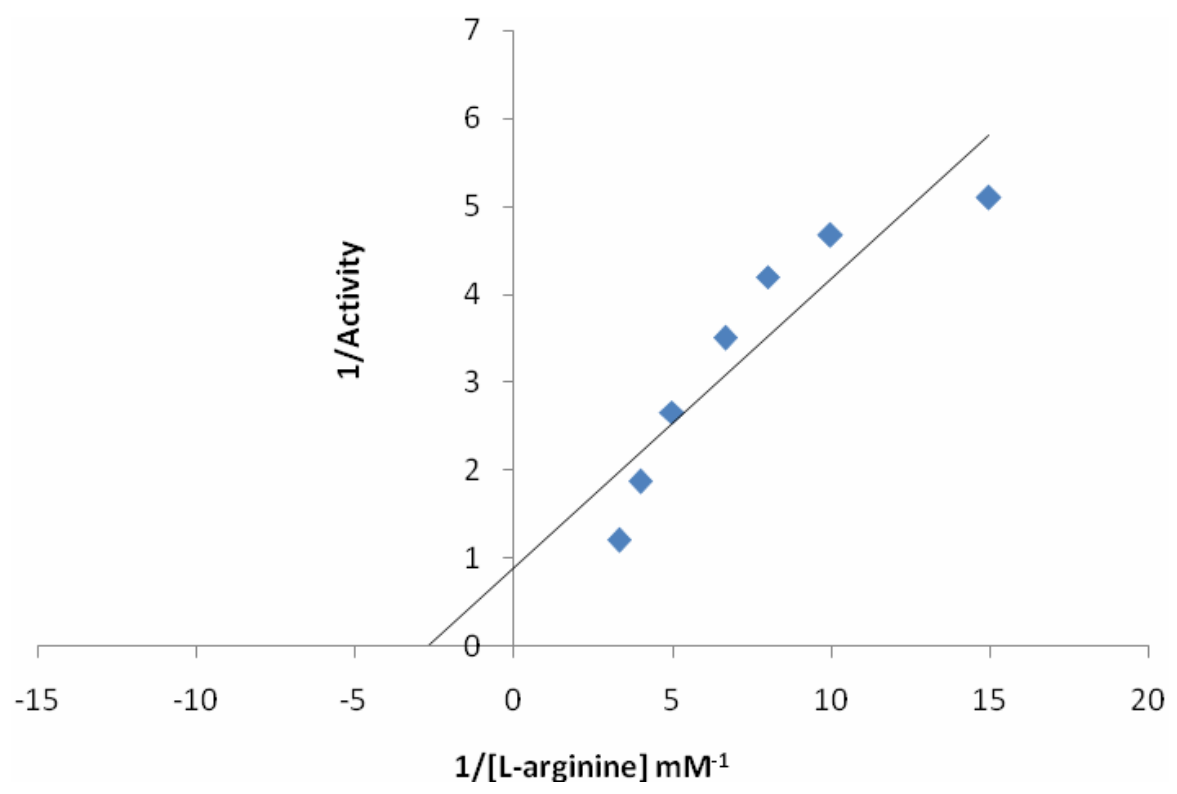

Figure 4: Lineweaver-Burk Plot. The $\mathrm{K}_{\mathrm{m}}$ of arginine was determined by varying the concentration of L-arginine between $40 \mathrm{mM}$ and $150 \mathrm{mM}$ in $2 \mathrm{mM}$ Tris- $\mathrm{HCl}$ buffer, $\mathrm{pH} 9.5$, in the presence of $0.01 \mathrm{mM} \mathrm{MnCl}_{2}$.

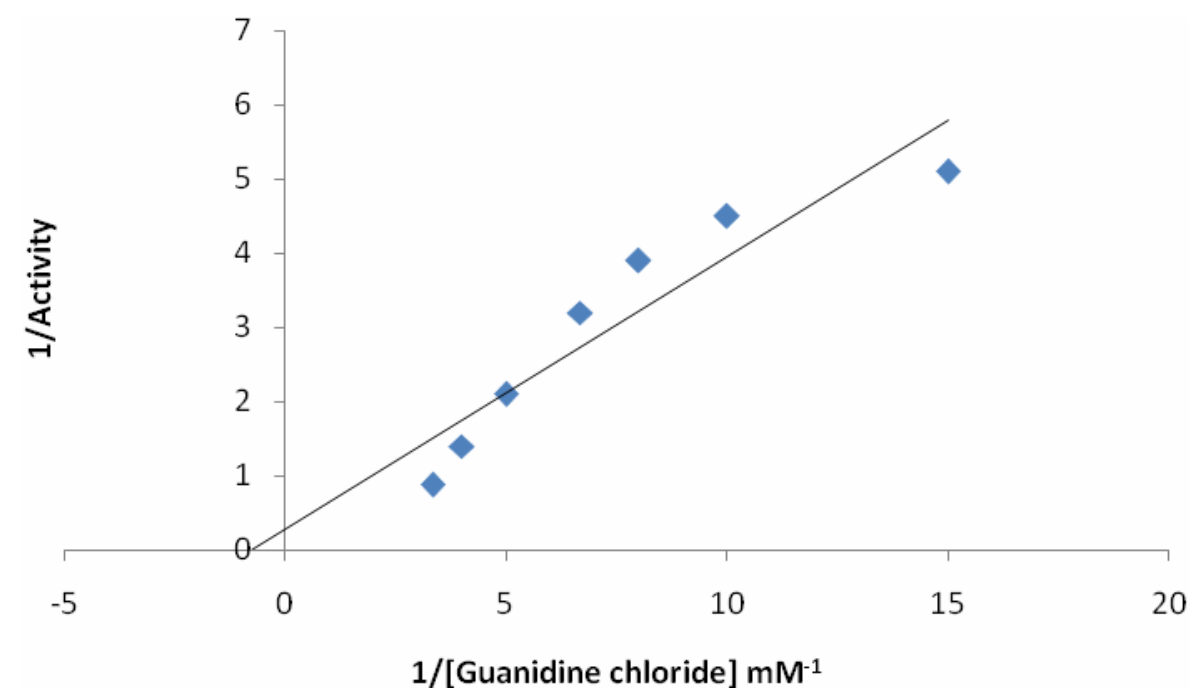

Figure 5: Lineweaver-Burk Plot. The $\mathrm{K}_{\mathrm{m}}$ of arginine was determined by varying the concentration of guanidine chloride between $40 \mathrm{mM}$ and $150 \mathrm{mM}$ in $2 \mathrm{mM}$ Tris- $\mathrm{HCl}$ buffer, $\mathrm{pH} 9.5$, in the presence of $0.01 \mathrm{mM} \mathrm{MnCl}_{2}$. 


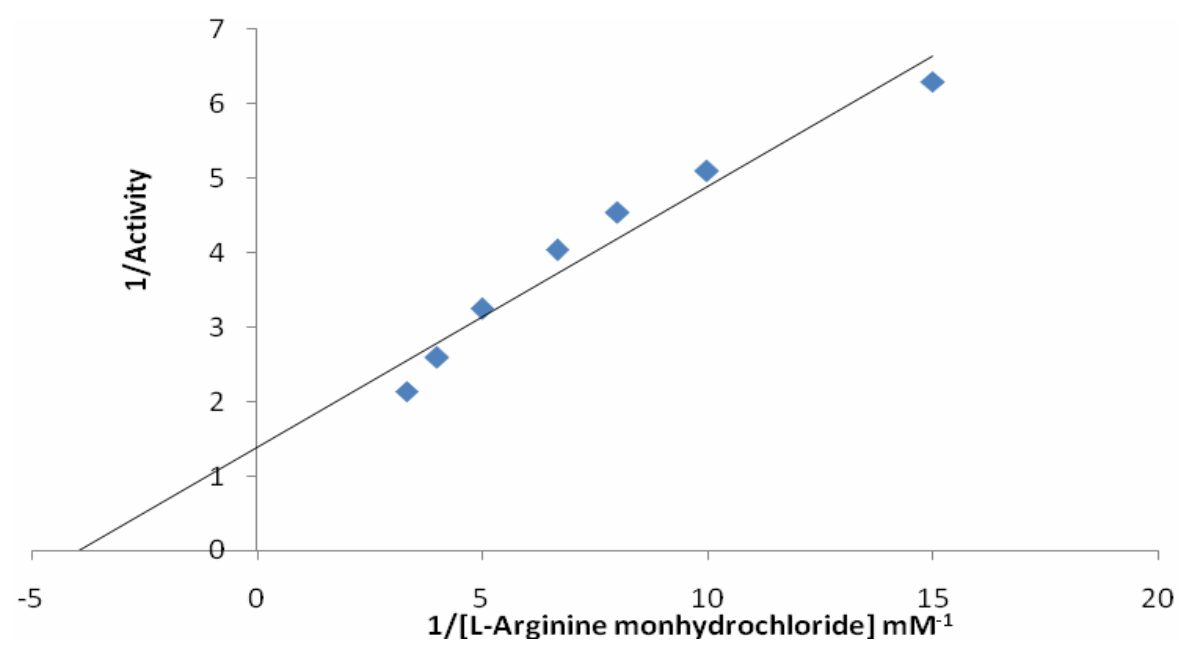

Figure 6: Lineweaver-Burk Plot. The $\mathrm{K}_{\mathrm{m}}$ of arginine was determined by varying the concentration of L-arginine monohydrochloride between $40 \mathrm{mM}$ and $150 \mathrm{mM}$ in $2 \mathrm{mM}$ Tris- $\mathrm{HCl}$ buffer, $\mathrm{pH} 9.5$, in the presence of $0.01 \mathrm{mM} \mathrm{MnCl}_{2}$.

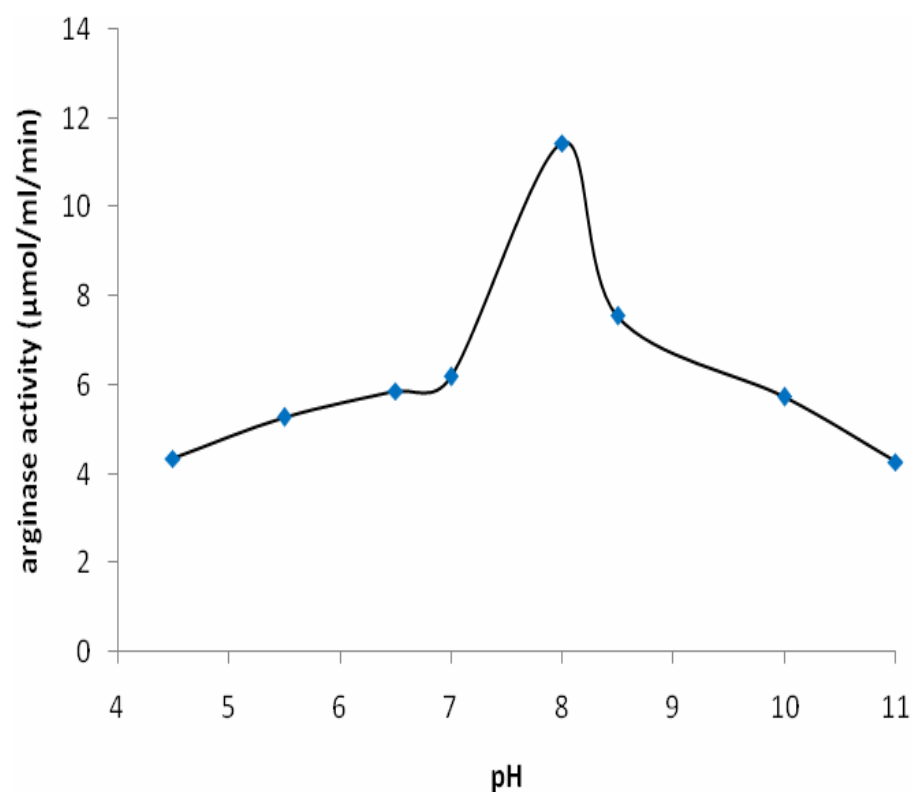

Figure 7: Effect of $\mathrm{pH}$ on the $Z$. variegatus arginase activity. One $\mathrm{ml}$ of the reaction mixture contained 2.5 $\mathrm{mM}$ of the appropriate buffer, $0.1 \mathrm{M}$ arginine and $0.02 \mathrm{ml}$ enzyme preparation. The following buffers of different $\mathrm{pH}$ values were used for the $\mathrm{pH}$ determination: $5 \mathrm{mM}$ citrate buffer ( $\mathrm{pH}$ 6.0-6.5), $5 \mathrm{mM}$ phosphate (pH 6.5-8.0), $5 \mathrm{mM}$ Tris-HCl buffer (pH 8.0-11.0). 


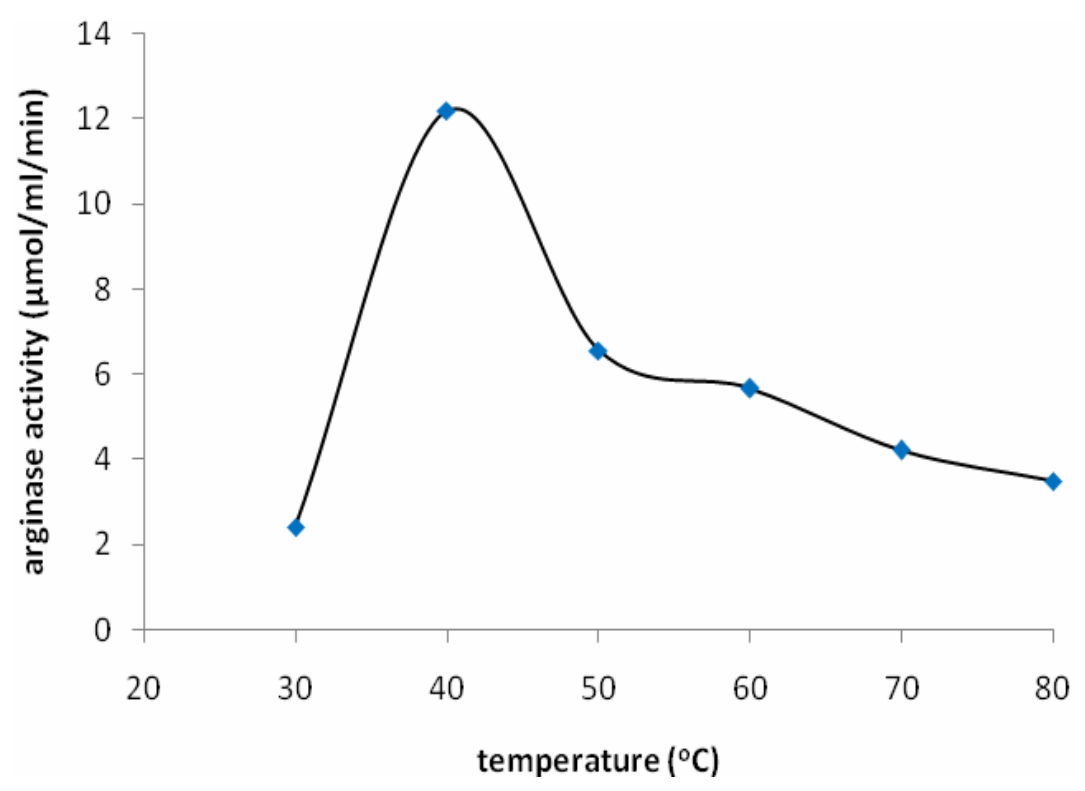

Figure 8: The activity-temperature profile showing the optimum temperature. The activity of $Z$. variegatus arginase was assayed at temperatures between $30^{\circ} \mathrm{C}$ and $100^{\circ} \mathrm{C}$. The assay mixture containing $50 \mu \mathrm{l}$ was first incubated at the indicated temperature for $10 \mathrm{~min}$ before initiating the reaction by the addition of an aliquot of the enzyme.

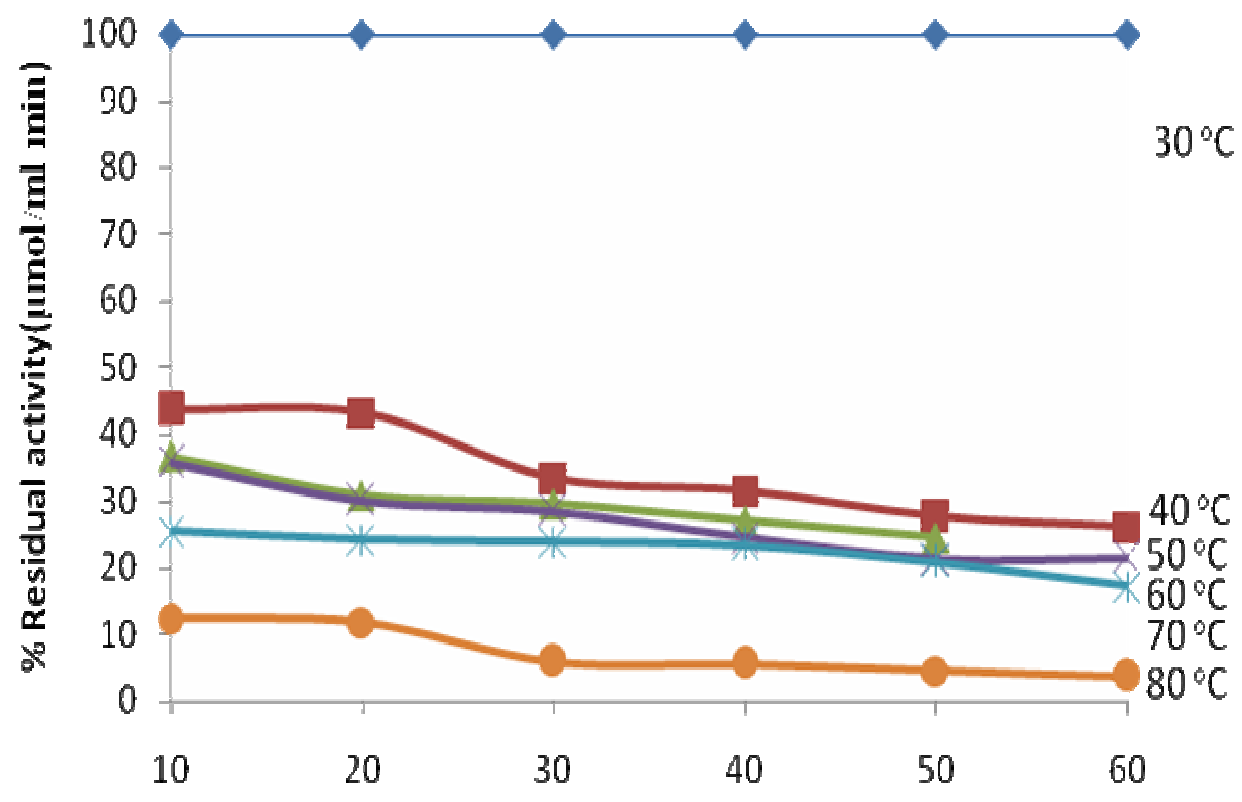

Time (min)

Figure 9: Effect of temperature on the stability of Z. variegatus arginase. An enzyme solution was incubated at the desired temperature and aliquots were withdrawn and assayed for residual activity at the various indicated time. The activities were expressed as percentage. 
Table 1: Summary of purification of $Z$. variegatus arginase.

\begin{tabular}{lcccccc}
\hline Fractions & $\begin{array}{c}\text { Total } \\
\text { Volume }(\mathbf{m l})\end{array}$ & $\begin{array}{c}\text { Total Activity } \\
(\text { Unit })\end{array}$ & $\begin{array}{c}\text { Total protein } \\
(\mathbf{m g})\end{array}$ & $\begin{array}{c}\text { Specific Activity } \\
(\text { Unit/mg) }\end{array}$ & $\begin{array}{c}\text { Purification } \\
\text { Fold }\end{array}$ & \% Yield \\
\hline $\begin{array}{l}\text { Crude } \\
\text { Extract }\end{array}$ & 320 & 12,410 & 9546.0 & 1.3 & 1 & 100 \\
\hline $\begin{array}{l}\text { Ion exchange } \\
\text { Extract }\end{array}$ & 175 & 8692 & 5216.8 & 1.7 & 1.3 & 54.6 \\
\hline Gel Filtration & 65 & 5211 & 1403.4 & 3.7 & 3.0 & 14.7 \\
\hline
\end{tabular}

Table 2: Summary of kinetic properties of different substrate for Z. variegatus arginase.

\begin{tabular}{lccc}
\hline & Arginine & Guanidine Chloride & L-Arginine monohydrochloride \\
\hline $\mathrm{K}_{\mathrm{m}}$ & 40 & 100 & 250 \\
$\mathrm{~V}_{\max }$ & 11 & 25 & 6.7 \\
\hline
\end{tabular}

Table 3: Effect of metal ion on Z. variegatus arginase activity.

\begin{tabular}{lc}
\hline Metal ions & $\mathbf{5 0 0} \boldsymbol{\mu M}$ \\
\hline $\mathrm{Zn}^{2+}$ & 65.2 \\
$\mathrm{NH}^{4+}$ & 100 \\
$\mathrm{Hg}^{2+}$ & 97.6 \\
$\mathrm{Na}^{+}$ & 100 \\
$\mathrm{Ni}^{+}$ & 80.5 \\
$\mathrm{Mn}^{2+}$ & 100 \\
\hline
\end{tabular}

Table 4: Inhibition effects of chelating and thio compounds on Z. variegatus arginase.

\begin{tabular}{lc}
\hline Chelating/Thio Compounds & \% Residual activity \\
\hline EDTA & 20.1 \\
Citrate & 17.3 \\
Ascobic acid & 14.8 \\
Urea & 22.7 \\
2-Mercaptoethanol & 31.5 \\
Cystein & 28.2 \\
\hline
\end{tabular}


Table 5: Effects of amino acids on the activity of $Z$. variegatus arginase

\begin{tabular}{lcc}
\hline & \multicolumn{2}{c}{ \% Residual Activity } \\
\cline { 2 - 3 } Amino acids & $\mathbf{5 0 ~} \mathbf{~ m M}$ & $\mathbf{1 0 0} \mathbf{~ m M}$ \\
\hline Proline & 98 & 95 \\
Lysine & 91 & 91 \\
Aspartate & 93 & 90 \\
Valine & 86 & 79 \\
Arginine & 100 & 100 \\
\hline
\end{tabular}

\section{DISCUSSION}

Arginase is an enzyme that is ubiquitous in nature and has been identified and studied for several decades in a large number of organisms (Jenkinson et al., 1996; Ash et al., 2000; Dabir et al; 2005; Mohamed et al., 2005; Scaraffia et al., 2008). Traniello et al. (1975) found two arginases in chicken kidney while Herzfeld and Raper (1976) reported the heterogeneity of arginase in rat tissues. A variety of functions has been proposed for the extrahepatic Type 2 arginase which includes the synthesis of ornithine for the production of glutamate and proline, control of cellular level of arginine and ornithine and synthesis of polyamines. New functions are been proposed for the arginase in different environments and organisms. Examples include its involvement in bulb growth and sprouting in plants, normal mammary gland development in rat, ammonia detoxification, hormone secretion, immune modulation and cellular replication in humans (Jenkinson et al., 1996; Shi et al., 2001; Todd et al., 2001). In vertebrates, as well as in insects, uric acid is produced by degradation of purines (Scaraffia et al., 2008). The production of urea in insects has been attributed to arginase, which catalyzes the hydrolysis of arginine to form urea and ornithine. However, unlike in vertebrates, where arginine is generated in the urea cycle, the action of arginase in insects is limited to arginine from dietary sources or from endogenous protein turnover (Scaraffia et al., 2008). This is because insects lack one or more genes encoding enzymes required for the urea cycle (Jenkinson et al., 1996; Scaraffia et al., 2008).

The specific activity of the arginase from Z. variegatus was $3.4 \mu \mathrm{mole} / \mathrm{min} / \mathrm{mg}$ of protein. The enzyme was purified through DEAE-Cellulose ion exchange chromatography and biogel P-100. Different specific activity values have been reported for non hepatic type 2 arginase from different sources. In Fasciola gigantical, arginase had very high activity compared to the other urea cycle enzymes (Mohamed et al., 2005). Molecular weight of $Z$. variegatus arginase was 143,000 dalton as determined by gel filtration. The molecular weight of yeast arginase was estimated to be 120,000 by Sephadex G-200 gel filtration (Chan and Cossins, 1973). The molecular weight of arginase II in $F$. gigantical as determined by gel filtration and SDS-PAGE, was 92,000 (Mohamed et al., 2005). Reddy and Campbell (1970) used gel filtration and density gradient centrifugation to estimate the molecular weight of arginase from the land planarian Bipalium kewense, land snail Helix aspersa and the laughing gull Larus atricilla. The molecular weight of arginases from land planarian and land snail was approximately 240,000 , while that from the gull was 120,000. Invertebrate arginases occur as large multimers (Mohamed et al., 2005). Arginase from human malaria parasite Plasmodium falciparum is a homotrimer of 160,000 dalton. Dialysis of the arginase against EDTA results in monomers of approximately 48,000 dalton 
(Muller et al., 2005). In contrast, small monomeric arginases of about 27,000 dalton have been encountered in the gut of the earthworms Lumbricus terrestris. A consideration of the known molecular weights of arginases from different species indicates there is no general correlation between the molecular weight of arginase from a given species and that species' excretory nitrogen metabolism.

The Michealis constant for arginine was $40 \mathrm{mM}$ for $Z$. variegatus gut arginase. This value was in the range of the $K_{m} s$ of invertebrate arginases which vary widely between $2 \mathrm{mM}$ in silkmoths and crayfish and up to $158 \mathrm{mM}$ in a polychaete annelid (Porembska, 1973; O'Malley and Terwilliger, 1974; Jenkinson et al., 1996; Dabir et al., 2005). The apparent Michaelis constant of $12.5 \mathrm{mM}$ and $250 \mathrm{mM}$ were obtained for arginine in two buffer systems (glycinate and phosphate buffers respectively) (Chan and Cossins, 1973). Mohamed et al. (2005) reported a $\mathrm{K}_{\mathrm{m}}$ of $6 \mathrm{mM}$ for $F$. gigantical. The $\mathrm{K}_{\mathrm{m}}$ value of Vigna catjang cotyledon arginase was $42 \mathrm{~K}_{\mathrm{m}}$ and is in the range of other reported $\mathrm{K}_{\mathrm{m}}$ (40-83 $\mathrm{mM}$ ) for plant arginases (Dabir et al., 2005). Arginine is a common substrate for the enzyme arginase (Jenkinson et al., 1996; Ensunsa et al., 2004). The activity of $Z$. variegatus arginase was highly specific for arginine. Studies have shown different arginine analogs to be good substrates for arginase; most arginases reported show preference for arginine as substrates (Jenkinson et al., 1996). Reczkowski and Ash (1992) reported the activity of guanidino compounds as alternate substrates for rat liver arginase and its dependent on the length of the amino acid side chain. The arginase present in the livers of uricotelic and ureotelic animals has similar substrate specificity (Mohamed et al., 2005).

The Z. variegatus enzyme exhibited a maximal activity at $\mathrm{pH}$ 8.0. F. gigantical showed maximum activity at $\mathrm{pH} \quad 9.5$ (Mohamed et al., 2005) while the pH optimum of $H$. niloticus was 5.5, the purified arginase of Helicobacter pylori had an acidic $\mathrm{pH}$ optimum of 6.1 (McGee et al., 2004). A pH of 10.0 was reported for Vigna catjang cotyledon arginase (Dabir et al., 2005). Acid-base status influences many aspects of insect biology, including insect distributions in aquatic systems, insect-plant and insect-pathogen interactions, membrane transport phenomena, and the mode of action of pesticides. Acidbase status in the hemolymph and gut lumen of insects is generally well regulated. The $\mathrm{pH}$ of the midgut lumen varies with the phylogeny and feeding ecology (Harrison, 2001). Insect fluids have buffer values similar to those of vertebrates. Evidence to date suggests that the dominant mechanisms for control of renal acid-base excretion involve hormonal regulation of $\mathrm{H}^{+}-\mathrm{V}$-ATPase activity (Punzo, 1988; Harrison, 2001).

Optimum temperature was recorded for Z. variegatus arginase at $40{ }^{\circ} \mathrm{C}$. Similar result was reported for $F$. gigantical (Mohamed et al., 2005). They further reported the stability of the enzyme at $40{ }^{\circ} \mathrm{C}$ for $15 \mathrm{~min}$ and at 50 ${ }^{\circ} \mathrm{C}$, the activity of the enzyme was completely lost. Similarly, arginase from fresh water teleostean fish Clarias batrachus was found to be stable between 10 and $37{ }^{\circ} \mathrm{C}$, its activity was decreased at higher temperature and showed no activity at $80{ }^{\circ} \mathrm{C}$ (Singh and Singh, 1988). For mammals, the optimum temperature for human vitreous humor arginase was $40 \quad{ }^{\circ} \mathrm{C}$ (Gursu, 2001). Furthermore, the enzymes in ectothermic animals such as $Z$. variegates and Periplanata americana have been adapted through natural selection to function at the range of temperatures experienced by these organisms. In general, the reaction rate of an enzyme catalyzed reaction increases by a factor of 2-3 for each $10{ }^{\circ} \mathrm{C}$ rise in temperature. Above about 40 degrees Celsius, enzymes will start to denature (unfold) and become nonfunctional (Diekman and Ritzmann, 1987).

Arginase is a metalloenzyme in which manganese acts as a cofactor as well as activator in almost all reported arginases (Ash, 2004; Dabir et al., 2005). Most arginases are 
activated by manganese (Jenkinson et al., 1996; Ensunsa et al., 2004; Mohamed et al., 2005). The effect of metals on $Z$. variegatus was similar to most of the inhibitory effects reported for arginases. $\mathrm{Mn}^{2+}, \mathrm{N}^{+}$and $\mathrm{NH}_{4}^{+}$ strongly activated the $Z$. variegatus enzyme where $\mathrm{Hg}^{2+}, \mathrm{Ni}^{2+}$ and $\mathrm{Zn}^{2+}$ showed slight inhibition on the enzyme. Dabir et al. (2005) reported that replacement of $\mathrm{Mn}^{2+}$ ion with other metal ions such as $\mathrm{Mg}^{2+}, \mathrm{Co}^{2+}, \mathrm{Ni}^{2+}$ and $\mathrm{Fe}^{2+}$ restored $\geq 50 \%$ activity, whereas $\mathrm{Ca}^{2+}$, $\mathrm{Zn}^{2+}$ and $\mathrm{Cd}^{2+}$ inhibited Vigna catjang cotyledon arginase. In buffalo liver arginase, $\mathrm{Mg}^{2+}$ activated the enzyme, but was inhibited by $\mathrm{Ca}^{2+}, \mathrm{Ni}^{2+}, \mathrm{Co}^{2+}, \mathrm{Cd}^{2+}, \mathrm{Fe}^{2+}$ and $\mathrm{Zn}^{2+}$ (Dabir et al., 2005). In F. gigantical, arginase enzyme was activated by $\mathrm{Mn}^{2+}$, but was inhibited by $\mathrm{Fe}^{2+}, \mathrm{Ca}^{2+}, \mathrm{Hg}^{2+}, \mathrm{Ni}^{2+}, \mathrm{Co}^{2+}$ and $\mathrm{Mg}^{2+}$ (Mohamed et al., 2005). Arginase activity was completely inhibited by in the presence of EDTA, citrate, ascorbic acid, and urea. Thio compounds (2-mercaptoethanol and Cystein) also inhibited the enzyme.

In our study, amino acids did not show any inhibitory effect, rather the arginase activity in the gut of $Z$. variegatus was enhanced. The presence of arginase and its high activity in the gut of $Z$. variegatus may suggest a major role for arginase in proline formation. Our finding is not uncommon with results obtained for the enzyme in other sources. Arginase was reported to have increased during adult development in winged adult moth; this was associated with increase in proline concentration, a major substrate utilized in insect flight metabolism (Reddy and Campbell, 1969). Proline has also been ascribed another function as an energy reservoir in insect flight muscle, where it is rapidly utilized during flight (Pant and Kumar, 1978, Matthias and Gerd, 2009).

In conclusion, the presence of arginase in the gut of Zonocerus variegatus could be for other functions rather than urea production in urea cycle. Insect arginase shows most of the properties characteristic of arginases from other animal and plant species. Both differences and similarities exist between it and the arginase present in uricotelic vertebrates.

\section{REFERENCES}

Ash DE. 2004. Structure and function of arginase. J. Nutr., 134: 2760-2764.

Ash DE, Cox JD, Christianson DW. 2000. Manganese and its Role in Biological Processes, Metal Ions in Biological Systems, (Vol 37) Sigel A Sigel H (eds). M. Dekker: New York, USA.

Bradford MM. 1976. A rapid and sensitive method for the quantification of microgram quantities of protein, utilizing the principle of protein dye binding. Anal. Biochem., 72: 248-254.

COPR (Centre for Overseas Pest Research). 1974. Control of Zonocerus variegatus (L) in Nigeria. Interim Report (19721973). ODM Research Scheme R2727, London.

Chan PY, Cossins EA. 1973. Arginine metabolism in Saccharomyces cerevisiae. Some general properties of yeast arginase. Plant and Cell Physiol., 14(4): 641-651.

Chiffaud J, Mestre J. 1990. Le Croquet Puant Zonocerus variegatus (Linne, 1758): Essaide Synthese Bibliographique. CIRAD-PRIFAS: Montpellier; 140.

Dabir S, Dabir P, Somvanshi B. 2005. Purification, properties and alternate substrate specificities of arginase from two different sources: Vigna catjang cotyledon and buffalo liver. Int. J. Biol. Sci., 1:114-122.

Diekman LJ, Ritzmann RE. 1987. The effect of temperature on flight initiation in the cockcroach Periplaneta Americana J. Neurobiol., 18(6): 487-496.

Ensunsa JL, Symons JD, Lanoue L, Schrader HR, Keen CL. 2004. Reducing arginase activity via dietary manganese deficiency enhances endothelium-dependent vasore- 
laxation of rat aorta. Exp. Biol Med., 229(11): 1143-53.

Gursu MF. 2001. Biochemical analysis of arginase and ornithine carbamoyltransferase in human vitreous humor. Arch. Med. Res., 32: 432-435.

Harrison JF. 2001. Insect acid-base physiology. Ann. Rev. Entomol., 46: 221250.

Herzfeld A, Raper SM. 1976. The heterogeneity of arginase in rat tissues. Biochem. J., 153: 469478.

Hwang HJ, Kim EH, Cho YD. 2001. Isolation and properties of arginase from a shade plant, ginseng (Panax ginseng) roots. Phytochem., 58(7): 10151024.

Idowu AB, Sonde OA. 2004. The contribution of food plants to the growth, development and fecundity of Zonocerus variegates (L). Nig. J. Entomol., 21: 24-28.

Jenkinson CP, Grody WW, Cederbaum SD. 1996. Comparative properties of arginases. Comp. Biochem. Physiol., 114B (1): 107-132.

Kaysen GA, Strecker HJ. 1973. Purification and properties of arginase of rat kidney. Biochem. J., 133: 779-788.

Lineweaver H, Burk D. 1934. The determination of enzyme dissociation constants. J. Am. Chem. Soc., 56: 658666.

Matthias WL, Gerd G. 2009. Hormonal regulation of energy metabolism in insects as a driving force for performance. Intergr. Comp. Biol., 49(4): 380-392.

McGee DJ, Zabaleta J, Viator RJ, Testeman TL, Ochoa AC, Mendz GL. 2004. Purification and characterization of Helicobacter pylori arginase, RocF: unique features among the arginase superfamily. Eur. J. Biochem., 271: 1952- 1962.

Mohamed SA, Fahmy AS, Mohamed TM, Hamdy SM. 2005. Urea cycle of Fasciola gigantica: Purification and characterization of arginase. Comp. Biochem. Physiol., 142: 308-316.

Muller IB, Walter RD, Wrenger C. 2005. Structural metal dependency of the arginase from human malaria parasite Plasmodium falciparum. Biol. Chem., 386: 117-126.

O'Malley KL, Terwilliger RC. 1974. Structure and Properties of arginase from the Polychaete Annelid Pista pacifica Berkeley. Biochem. J., 143: 591-597.

Pant R, Kumar S. 1978. Is a Urea Cycle Present in Insects? Biochem. J., 174: 341344.

Porembska Z. 1973. Different species of arginase in animal tissues. Enzyme, 15: 198-209.

Punzo F. 1988. Effects of low environmental $\mathrm{pH}$ and temperature on hatching and metabolic rates in embryos of Anax junius drury (Odonata: Aeshnidae) and the role of hypoxia in the hatching process. Comp. Biochem. Physiol., 91(2): 333-336.

Reczkowski RS, Ask DE. 1992. EPR evidence for binuclear Mn (II) centers in rat liver arginase. J. Am. Chem. Soc., 114: 1099210994.

Reddy SRR, Campbell JW. 1969. Arginine metabolism in insect. Properties of insect fat body arginase. Comp. Biochem. Physiol., 28B: 515- 534.

Reddy SRR, Campbell JW. 1970. Molecular weights of arginase from different species. Comp. Biochem. Physiol., 32B: 499-509.

Sampaleanu LM, Yu B, Howell PL. 2002. Mutational analysis of duck delta 2 crystallin and the structure of an inactive mutant with bound substrate provide insight into the enzymatic mechanism of argininosuccinate lyase. $J$. Biol. Chem., 277(6): 4166-4175.

Scaraffia PY, Tan G, Isoe T, Wysocki VH, Wells MA, Miesfeld RL. 2008. Discovery of an alternate metabolic pathway for 
urea synthesis in adult Aedes aegypti mosquitoes. PNAS., 105(2): 518-523.

Shi OU, Morris MS, Zoghbi J, Porter CW, O'Brien EW. 2001. Generation of a mouse model for arginase II deficiency by targeted disruption of the arginase II gene. Molecul. Cellul. Biol., 21: $811-813$.

Singh RA, Singh SN. 1988. Tissue arginase associated with urea synthesis and nitrogen metabolism in Clarias batrachus. Biochem. Sys. Ecol., 16(3): 359-363.

Todd DC, Cooke JEK, David JG. 2001. Purification and properties of Pinus taeda arginase from germinated seedlings. Plant Phys. Biochem., 39(12): 1037-1045.
Toye SA. 1982. Studies on the biology of the grasshopper pest Zonocerus variegatus (L) (Orthoptera: Pyrgomorphidae) in Nigeria. Insect Sci. Its Application, 3: 17.

Traniello S, Barsacchi R, Magri E, Grazi E. 1975. Molecular Characteristics of Chicken Kidney Arginase. Biochem. J., 145: 153-157.

Yu H, Yoo PK, Aguirre CC, Tsoa RW, Kern RM, Grody WW, Cederbaum SD. 2003. Widespread expression of arginase I in mouse tissues. Biochemical and physiologicalimplications. $J$ Histochem Cytochem., 51: 1151-1160. 